\title{
CULTURAL MODELS OF DISABILITY. AN EXPLORATORY QUALITATIVE STUDY ON THE PRE-SERVICE TEACHERS' ATTITUDES AND SOCIAL REPRESENTATIONS
}

\author{
Andrea Fiorucci \\ Department of History, Society and Human Studies, University of Salento (Italy)
}

\begin{abstract}
Attitudes towards disability and inclusion are the result of the representations that people create and share during social interaction: they are an individual interpretation of a collective belief (Salès-Wuillemin, 2006; Ramel, 2014). Starting from this perspective, the paper show the results of a study conducted between 2017 and 2018 on representations of disability and on the fears of a group of pre-service teachers. From the aspects highlighted by the study, emerges the need to continue to insist on the study of representations and attitudes of teachers, also in view of the complexification of social scenarios and the cultural approach to differences at school.
\end{abstract}

Keywords: Representations, disabilities, inclusion, pre-service teachers.

\section{Cultural representation of disability}

The Italian cultural approach to disability was started more than forty years ago by the laws on school integration (L. 118, 1971; L. 517, 1977; L. 104, 1992) and recently enriched by the ministerial indications on Special Educational Needs (Ministerial Directive, 2012; Ministerial Circular n. 8, 2013).

In recent years, ideas began to positively change about special teaching and education. Attitudes continued to change, because teachers began to see the transformative value of education.

In response to this, there is a growing body of literature which argues that teachers' attitudes and representations regarding disability and inclusion play a central and predictive role for the promotion and management of school inclusion (Chong, Forlin \& Au, 2007; Lambe \& Bones, 2007). There appears to be broad consensus that teachers' attitudes toward inclusion is critical in implementing the ambitious goal of inclusive schools for all. Teachers' positive attitudes towards disability are one of the most important factors that determine and facilitate inclusive practices and processes. Attitudes towards disability are the result of the representations that people create and share during social interaction: they are an individual interpretation of a collective and cultural belief (Salès-Wuillemin, 2006; Ramel, 2014). They are the result of the representations that people create and share during social interaction (Ramel, 2014). Social representations are subsystems conditioned by broad ideological systems, while attitudes are single interpretations of a common reference system, and therefore are in a lower level of analysis, an interindividual level (Doise, 1989; Rateau, 2000). According to Rouquette (1996), in fact, ideology constitutes the matrix of representations, which are the matrix of attitudes. Although with an object of very broad analysis, the theory of social representations (Moscovici, 1961, 1984) offers a remarkable contribution to the study of perceptions and attitudes on disability, as it allows reflection on the social dimension of knowledge and on the processes of interpretation and co-construction connected to it. The representations "make familiar" (Moscovici, 1984) and socially shareable what we perceive and which is still little known. Disability can be represented through two processes: anchoring, which allows us to understand what is not familiar, putting it in relation with the categories possessed and objectification, which translates into images difficult concepts. Complex and abstract ideas are objectified through personification, use of people to represent an idea, figuration, use of concrete images and ontologization, the use of physical properties to represent an idea.

The various studies that have analyzed the contribution of social representations of disability in the educational setting (Savarese, 2009; Consiglio, Guarnera and Magnano, 2015) and in relation to the teachers' perceptions (Federici \& Meloni, 2009; Samsel \& Perepa 2013; Ramel, 2014; Savarese \& Cuoco, 2015; St-Onge \& Lemyre, 2016). Teachers' representations and the attitudes that derive from them carry out a key role for the realization of a culture of inclusion at school. Among the representations of 
disability and inclusion there is mutually conditioning link (Lamontagne-Müller \& Gygax, 2009). As other recent studies confirm, often the representations of the teachers in formation appear very close to the common sense, mostly stereotyped and prototypical (Fiorucci, 2018, Ramel, 2014), and often influenced by the fear of disability (Disanto, 2015). The didactic-educational practice is largely influenced by the opinions that the teacher has of the nature of disability (Jordan, Schwartz \& McGhie-Richmond, 2009). Furthermore, the decisive role played by the experience of contact with disabled people should also be considered (Falanga, de Caroli \& Sagone, 2011; Wong, 2008; Fiorucci, 2018). On a more general level, studies show a growing tendency to recognize to people with disabilities the right to be educated in common contexts (Forlin, 2011; Sharma, Forlin \& Loreman, 2008), thus considering Italian school integration a virtuous model to strive for (Kanter, Damiani \& Ferri, 2014). In Italy, according to the perception of teachers, the effectiveness of inclusion lies above all in the social elements, rather than on a real improvement in the development of the person with disability in the school context (Ianes, Demo \& Zambotti, 2011). Even if inclusion appears as an inalienable right and an inalienable social justice project that interests everyone, the progressive establishment of the scholastic communication of medical-specialist language, replacing the pedagogical language (Medeghini, 2007), supports the stigmatization process, which reduces the complexity of the person "with" disability to the diagnosis and certification of his/her deficit (Fiorucci, 2016; TreeLLLE Association, Caritas Italiana \& Fondazione Agnelli, 2011).

\section{Research design and methodology}

Scientific literature indicates as important variable pre-service teacher training (Chong, Forlin \& Au, 2007, Lambe \& Bones, 2007), because it influences the teaching effectiveness and the educational relationship (Sharma, 2012): teachers who have taken part in specific training courses are closer to scholastic inclusion. Training is an important opportunity to guide future teachers to reflect, evolve, change their attitudes towards disabilities and inclusion. Starting from this perspective, this article reports the results of a descriptive-exploratory study ${ }^{1}$, conducted between 2017 and 2018, that investigated representations of disability of pre-service teachers involved in the Support disabilities specialization Course (CS) and Primary School Teacher Training Course (SFP) at the University of Salento (Lecce, Italy).

\subsection{Participants}

The research involved 167 participants from Puglia (southern Italy region), mostly women (91\%) and members of the CS (79\%), with an average age between 25 and 50 years. The order of school that collects the largest participants is the one related to the first degree (29.9\% childhood and $28.7 \%$ primary CS, $21 \%$ childhood and primary SFP).

\subsection{Procedures and data analysis}

The research uses portraiture and narrative inquiry methodology to examine a range of issues around pre-service teachers' knowledge and understanding of disability representations and the implications of these understandings on their teaching practice. We have made use of focus group technique, a particular type of group interview that aims to produce data on a specific analysis topic, by comparing the participants: 14 group discussions of 70 minutes were planned, made up of about 12 people, each of them belonging to the same school order and professional status (CS or SFP). On the narrative corpus, was carried out qualitative analysis aimed at identifying the cultural repertoires, interpreted through the anchoring and objectification processes by the Social Representations Theory.

\subsection{Results}

From a general point of view, it is possible to highlight that the emerged representations are highly recurrent and superimposable within the focus groups, with slight differences found in the comparison between the different school orders. The perceptions of future teachers on disability (table 1) take as their starting point not the processes of marginalization and school exclusion, but the medical and individual condition of disability. The focus of attention is diverted on the deficit, on the diagnosis, on its lack, on the mal-functioning of the person. All this emerges from highly medicalized and medicalizing discursive modalities, which seem to prefer diagnostic labels that multiply and differentiate according to the different etiologies examined, to a pedagogical and educational lexicon.

${ }^{1}$ The study is part of the research program "Cultural models of difference and promotion of inclusion at school", scientific director Professor Stefania Pinnelli at Department of History, Society and Human Studies, University of Salento. 
Table 1. Representations of disability.

\begin{tabular}{|c|c|c|c|}
\hline & SFP & $\begin{array}{c}\text { CS } \\
\text { childhood-primary } \\
\text { school }\end{array}$ & $\begin{array}{c}\text { CS secondary } \\
\text { school }\end{array}$ \\
\hline Anchoring & $\begin{array}{l}\text { hearing impairment } \\
\text { vision impairment } \\
\text { motor deficit } \\
\text { diagnosis/certification } \\
\text { SEN }\end{array}$ & $\begin{array}{c}\text { Down syndrome } \\
\text { autistic syndrome } \\
\text { diagnosis/certification } \\
\text { SEN }\end{array}$ & $\begin{array}{c}\text { hearing impairment } \\
\text { vision impairment } \\
\text { intellectual deficit } \\
\text { motor deficit } \\
\text { diagnosis/certification }\end{array}$ \\
\hline Figurations & $\begin{array}{l}\text { wheelchair } \\
\text { chains } \\
\text { cage } \\
\text { support } \\
\text { barriers } \\
\text { dead end }\end{array}$ & $\begin{array}{c}\text { wheelchair } \\
\text { disabled parking } \\
\text { triangle-rumble } \\
\text { dark room } \\
\text { cage } \\
\text { stumbling block } \\
\text { silkworm } \\
\text { land to grow }\end{array}$ & $\begin{array}{c}\text { wheelchair } \\
\text { disabled parking } \\
\text { dark } \\
\text { cage } \\
\text { wall } \\
\text { open bridge } \\
\text { closed door } \\
\text { labyrinth } \\
\text { toy without batteries }\end{array}$ \\
\hline Personification & $\begin{array}{l}\text { pupil with disabilities } \\
\text { acquaintance } \\
\text { disabled artist or } \\
\text { sportsman }\end{array}$ & $\begin{array}{l}\text { pupil with disabilities } \\
\text { relative } \\
\text { acquaintance }\end{array}$ & $\begin{array}{l}\text { pupil with disabilities } \\
\text { acquaintance }\end{array}$ \\
\hline Emotions & $\begin{array}{c}\text { sadness } \\
\text { anger } \\
\text { discouragement }\end{array}$ & $\begin{array}{c}\text { fear } \\
\text { anxiety }\end{array}$ & $\begin{array}{l}\text { solitude } \\
\text { exclusion }\end{array}$ \\
\hline
\end{tabular}

The radicalization of a typically bio-medical look in a group of non-professionals, pre-service teachers, as well as diverting attention from the person universe causes re-proposed diagnostic and hoary labels (for example, the "deaf-mutes", the "mentally handicapped"), often spoiled by stereotypes and easy generalizations. Among the most recurring figures we find the image of the wheelchair which has now become the emblem of disability (fig. 1). The symbol also returns in the stylized image of the person in a wheelchair on a blue background, the one invented by Koefoed in 1968, mentioned by the participants as a symbol for road signs, for the handicap parking permit and, in general, to indicate services or accessible places for the disabled.

Figure 1. Representations of disability.

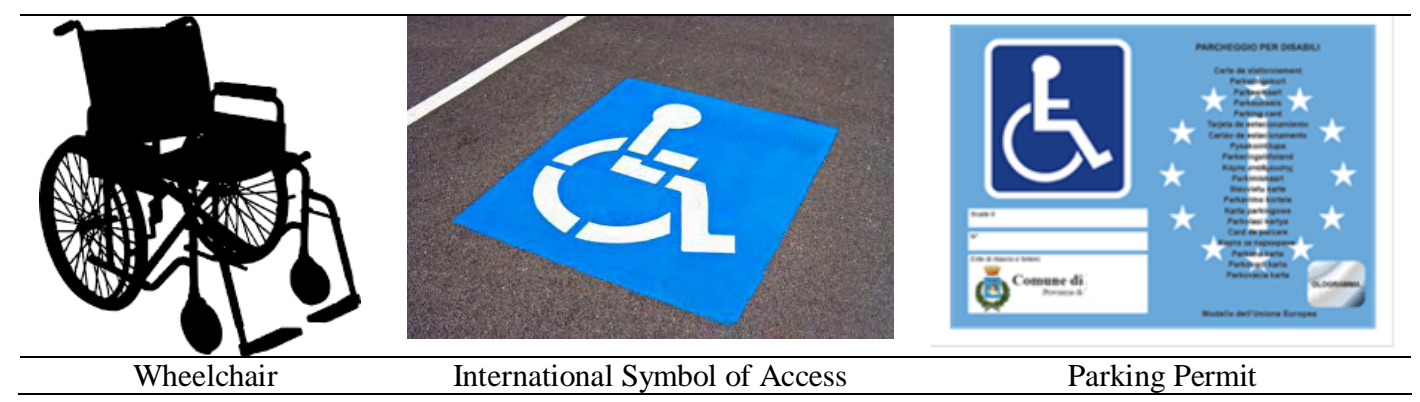

On a more abstract level, the disability representations convey meanings that further exacerbate the medical-individual vision already emerged, associating images that recall the sense of limitation, of constraint, of the absence of a pathway. In the image of the cage that segregates, of the blocking wall, of the labyrinth that disperses, of the open bridge that does not communicate, of the door that prevents passage, of the triangle and the rhombus that have edges, the images present in most of the participants add to the key word "deficit" those semantically closest: limit and obstacle. In confirmation of the traced picture, the representations are in line with the emotions and the negative feelings expressed by the teachers in formation. In the other direction, instead, the images of a silkworm, of a toy to which the batteries must be added, of a land that must be made fertile are favorably directed to recognize the presence of a potential to be cultivated. Finally, from the analysis of the representations emerges the personification of disability images, evident from the need expressed by the participants to draw from their professional experiences and life, leading them to fathom their memories. The representations now 
take on the face of a friend, of a student, sometimes of a person absent-mindedly met on the street, thus making their images less abstract, realistically more familiar.

In addition to the representations, the teachers' fears also emerge. The fear of not being able to face the problems linked to the deficit and integration of their pupils is more evident, a renouncing attitude and not always inclined to try to change the course of events. It is an attitude related to the perception of the self that does not feel able to exercise any control over the events, with possible drifts on the self-efficacy and self-esteem of the future teacher. To the fear of not making the acquired cultural preparation expendable, the teacher has the fear of not being sufficiently prepared and competent; not knowing how to exercise good and functional didactic mediation. Fear of failure is also expressed in the relational area: there are growing concerns about not being able to make the classroom climate truly inclusive, not knowing how to concretize the school-family co-responsibility pact, of not being able to activate a good collaboration between colleagues, be empathetic and welcoming with their disabled pupils. But the fears that most frighten future teachers are those of resignation, of not feeling gratified, of not seeing progress in their work of educational care. Regarding the specific disability, the participants of the primary school are worried about not knowing the communication codes for the deaf pupil and for the braille code for the blind student. Participants in secondary education are afraid to exercise more assistance than teaching, or, in the presence of intellectual disabilities, they are afraid not to calibrate the teaching intervention or not to make accessible learning content.

\section{Conclusion}

The picture that emerges from the research is complex. Stereotyped and prototypical images of disabilities emerge This is proof of the anchoring of perceptions to a culture of the fragment-deficit, to a bio-medical view of disability marked also by a certain degree of commiseration and resignation. It seems, in fact, that among the participants there is a "diagnosis hunt" (Pinnelli, 2015), that there is a sort of epidemic of the SEN at school. Often, we use the one that Goussot (2015) defines as "the lens of clinical diagnosis", that gaze that puts the accent on the symptoms, on the inability and on the problems. In this way the indissociable unit person disappears, that entirety emphasized by the biopsychosocial perspective of the ICF (WHO, 2001). Emerges first is the deficit and then the person, first the wheelchair of the disabled person and after the disabled person. The disability picture is completed by images that recall the sense of limit and obstacle, a picture that becomes even more complex to the extent that you look with prejudice and fear what you would never want to become. The relationship with disabled person is not entirely easy and natural, indeed, destabilizes, is scary. It is the fear of difference, the fear of the myths surrounding people with disabilities, the fear that comes from that "tyranny of normality" of which, according to Kristeva and Vanier (2011), one is slaves. Like a broken mirror (Sausse, 2006), the person with disability still represents an image that is scary and from which we often prefer to look away. The biggest fear, even greater than the complexity of the deficit, is another: that of failure. The prefiguration of difficult situations causes feelings of anxiety, of loss, of impotence to emerge, but also the desire for continuous change, not to stagnate in excessively complex situations that reduce the role of the teaching mediator in an assistant to the person. The fear of disability is associated with not being able to support the difference of one's pupil, but also that of not being able to bear the difference that a supporting educational-educational role imposes. The stereotypical and medicalized views of disability, as well as the fears of future teachers have a function that is to say the least fundamental, because they highlight the fragility of a difficult job, as that of supporting the person with disability, showing aspects not only content but above all emotional-relational and experiential on which we should focus more.

\section{References}

Associazione TreeLlLe, Caritas Italiana \& Fondazione G. Agnelli (2011). Rapporto alunni con disabilità. Bilancio e proposte. Trento: Erickson.

Chong S., Forlin C., Au M.-L. (2007). The Influence of an Inclusive Education Course on Attitude Change of Pre service Secondary Teachers in Hong Kong. Asia-Pacific Journal of Teacher Education, 35(2), 161-179.

Consiglio A., Guarnera M., Magnano P. (2014), La rappresentazione della disabilità nei bambini. Una verifica dell'ipotesi del contatto a scuola. Scienze e Ricerche n. 1, 105-114.

Disanto A.M. (2015). Alcune considerazioni sulla relazione insegnante e allievo disabile: Analisi di un'esperienza, International Journal of Psychoanalysis and Education, 7(2), 20-32.

Doise, W. (1989). Attitudes et représentations sociales. In D. Jodelet (Ed.) Les représentations sociales. (p. 220-238). Paris : Presses Universitaires de France. 
Falanga R., de Caroli M. E., Sagone M. E. (2011). Attitudes towards disability: The experience of "contact" in a sample of Italian college students. Journal of Developmental and Eduational Psychology, 1(4), 91-99.

Federici, S., Meloni, F. (2009). Making Decisions and Judgments on Disability: The Disability Representation of Parents, Teachers, and Special Needs Educators. Journal of Education, Informatics and Cybernetics, 1(3), 20-26.

Fiorucci A. (2016). L'inclusione a scuola. Una ricerca sulle percezioni di un gruppo di insegnanti in formazione e in servizio. Form@re - Open Journal per la formazione in rete, 16(3), 20-34.

Fiorucci A. (2018). Le rappresentazioni della disabilità visiva di un gruppo di futuri insegnanti: una ricerca sul contributo della formazione iniziale e dell'esperienza del contatto. Italian Journal of Special Education for Inclusion, 6(2), 161-178.

Forlin, C. (2011). Teacher education reform for enhancing teachers' preparedness for inclusion. International Journal of Inclusive Education, 14(7), 649-654.

Goussot A. (2015), I rischi di medicalizzazione nella scuola. Paradigma clinico-terapeutico o pedagogico?, Educazione democratica, Rivista di pedagogia politica, 9, 15-47.

Ianes, D., Demo, H., \& Zambotti, F. (2011). Gli insegnanti e l'integrazione. Atteggiamenti, opinioni e pratiche. Trento: Erickson.

Jordan, A, Schwartz, E, \& McGhie-Richmond D. (2009). Preparing teachers for inclusive classrooms. Teaching and Teacher Education, 25(4), 535-542

Kanter, A., Damiani, M., \& Ferri, B. (2014). The Right to inclusive education under international law: following Italy's lead. Journal of International Special Needs Education, 17(1), 21-32.

Kristeva J. e Vanier J. (2011). Il loro sguardo buca le nostre ombre. Dialogo tra una non credente e un credente sull' handicap e la paura del diverso. Roma: Donzelli editore.

Lamontagne-Müller L., Gygax P.(2009), Le modèle social/environnemental du handicap : un outil pour sensibiliser les enseignantes et les enseignants en formation, Formation et pratiques d'enseignement en questions, 9, 77-95.

Medeghini, R. (2007). Idee di differenze. Rappresentazioni e prassi per le disabilità nella formazione professionale di Bergamo e provincia. Brescia: Vannini.

Moscovici S. (1961). La psychanalyse, son image et son public. Paris: Presses Universitaires de France.

Moscovici S. (1984). The Phenomenon of Social Representations. In R. Farr, S. Moscovici (Eds). Social representations. Cambridge: Cambridge University Press.

Pinnelli S. (2015). Scuola e alunni BES: tra buone e cattive tentazioni. Educazione democratica, Rivista di pedagogia politica, 9, 70-83.

Ramel S. (2014). Elèves en situation de handicap ou ayant des besoins éducatifs particuliers: quelles représentations chez de futurs enseignants? Revue suisse de pédagogie spécialisée, 3, 20-26.

Rateau, P. (2000). Idéologie, représentation sociale et attitude : étude expérimentale de leur hiérarchie. Revue internationale de Psychologie sociale, 13(1), 29-57.

Rouquette, M.L. (1996). Représentation et idéologie. In J.-C. Deschamps et J.-L. Beauvois (Ed.), Des attitudes aux attributions (p. 163-173), Grenoble : Presses universitaires de Grenoble.

Salès-Wuillemin E. (2006). La catégorisation et lesstéréotypes en psychologie sociale. Paris: Dunod.

Samsel M., Perepa, P., (2013). The impact of media representation of disabilities on teachers' perceptions. Support for Learning. 28.

Sausse S. (2006), Specchi infranti. Uno sguardo psicoanalitico sull'handicap, il bambino e la sua famiglia, Torino: Ananke.

Savarese G, Cuoco R. (2015). Le rappresentazioni sociali della disabilità nei docenti e nei genitori, Educare.it, rivista on line, 15(1).

Savarese G. (2009), Io e il mio amico disabile. Milano: Franco Angeli.

Sharma, U., Forlin, C., \& Loreman, T. (2008). Impact of training on pre-service teachers' attitudes and concerns about inclusive education and sentiments about persons with disabilities. Disability \& Society, 23(7), 773-785.

St-Onge, M., Lemyre, A. (2016). Les variables associées à l'attitude du personnel enseignant du secteur collégial vis-à-vis des étudiantes et des étudiants présentant un trouble de santé mentale. Éducation et francophonie XLIV (1), 154-172.

WHO (2001). International Classification of Functioning, Disability and Health. Geneva: WHO.

Wong, D. (2008). Do contacts make a difference? The effects of mainstreaming on student attitudes toward people with disabilities. Research in Developmental Disabilities, 29, 70-82. 